\title{
原著
}

\section{SIGNIFICANCE OF DNA PLOIDY PATTERN IN DIAGNOSIS OF OVARIAN TUMOR}

\author{
Department of Obstetrics and Gynecology Jikei University School of Medicine \\ Masahisa Ogawa, M.D., Hiroshi Sasaki, M.D., Yoshiteru Terashima, M.D.
}

DNA ploidy pattern of paraffin-embeded block from 67 patients with 10 benign, 41 malignant and 16 ovarian tumors of low malignant potential (LMP) were analysed by flow cytometry. Staining for DNA analysis was achieved with propidium iodide. All of 10 benign ovarian tumors exhibited only diploid cells. Tumor with aneuploidy or multiploidy pattern were found in $85.4 \%$ of carcinomas. Of the 16 tumors of LMP, almost tumors were diploid like adenoma, but only one was multiploid and had a episode of recurrence after 4 years interval.

Our results suggest that estimation of DNA ploidy pattern may be used as an additional diagnostic tool supplementing conventional histopathologic evaluation of ovarian tumors of LMP, but prolonged follow-up and increased patient accrual is necessary to assess whether the flow cytometric analysis will provide practical importance.

Key wards : Ovarian tumor-Flow cytometry-Low malignant potential-DNA ploidy pattern

\section{INTRODUCTION}

Epithelial ovarian tumors with a tumor status between benign and malignant are classified as tumors of low malignant potential (LMP), also refers to as borderline tumors. According to the report by the Ovarian Tumor Registration Committee of Japan Society of Obstetrics and Gynecology collected from 56 institutions during the period from 1975 to 1980 , tumors of LMP occurred in 460 cases that acconted for $20.6 \%$ of ovarian epithelial malignant

卵巣腫瘍診断における DNA ploidy pattern の意義 小川雅久, 佐々木賽, 寺島芳輝, 東京慈恵会医科大学産婦人科学教室 論文別刷請求先 函105 東京都港区西新橋 3019 の 18 東京 慈恵会医科大学産婦人科 小川雅久

昭和 63 年 8 月 23 日受付

昭和 63 年 10 月 14 日受理 tumors in Japan, and this incidence is slightly higher than that in foreign countries, 10 to $15 \%$ of epitherial ovarian tumors reported by many foreign investigators. The report revealed LMP occurred at an earlier age and stage than frank malignancy and its prognosis was good and clinical stage was less accurate indication of eventual outcome than a case in frank malignancy. Unfortunately, late recurrences were noted and pathology of recurrent tumor was changed to frank malignancy in some cases.

The key morphologic feature that separates the tumors of LMP from frank malignancy is the luck of stromal invasion. Stromal invasion, of course, is seen in frank malignancy. But identification of invasion is not always easy especially in mucinous tumors because of their small secondary cysts. Evaluation of other architectual as well as cytological features is a challenging problem. 
Table 1 Clinical and Histologic Characteristics of the 41 Cases of Ovarian Carcinoma: Relation to DNA Ploidy

\begin{tabular}{|c|c|c|c|c|}
\hline & \multirow{2}{*}{$\begin{array}{l}\text { No. of } \\
\text { cases }\end{array}$} & \multicolumn{3}{|c|}{ DNA ploidy pattern } \\
\hline & & $\begin{array}{l}\text { Normal } \\
\text { No. }\end{array}$ & No. & $\begin{array}{c}\text { Abnormal } \\
\text { (Aneuploid, Multiploid) }\end{array}$ \\
\hline All patients & 41 & 6 & 35 & $(23,12)$ \\
\hline 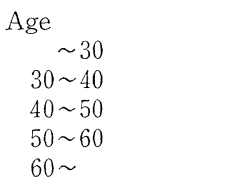 & $\begin{array}{r}1 \\
1 \\
14 \\
20 \\
3\end{array}$ & $\begin{array}{l}0 \\
0 \\
3 \\
2 \\
1\end{array}$ & $\begin{array}{r}1 \\
1 \\
11 \\
18 \\
2\end{array}$ & 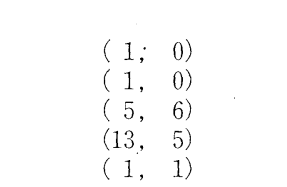 \\
\hline $\begin{array}{l}\text { Stage } \\
\text { I } \\
\text { II } \\
\text { III } \\
\text { IV } \\
\text { Rec. }\end{array}$ & $\begin{array}{r}13 \\
4 \\
15 \\
0 \\
9\end{array}$ & $\begin{array}{l}0 \\
1 \\
4 \\
0 \\
1\end{array}$ & $\begin{array}{r}13 \\
3 \\
11 \\
0 \\
8\end{array}$ & 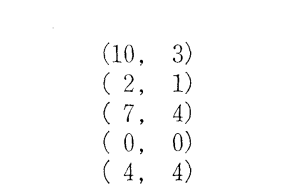 \\
\hline $\begin{array}{l}\text { Histologic type } \\
\text { Serous } \\
\text { Mucinous } \\
\text { Endometrioid } \\
\text { Clear cell } \\
\text { ^Unclassified } \\
\text { Undifferentiated }\end{array}$ & $\begin{array}{r}8 \\
12 \\
6 \\
7 \\
3 \\
5\end{array}$ & $\begin{array}{l}3 \\
1 \\
0 \\
0 \\
0 \\
2\end{array}$ & $\begin{array}{r}5 \\
11 \\
6 \\
7 \\
3 \\
3\end{array}$ & 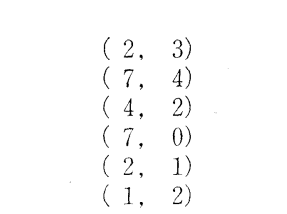 \\
\hline $\begin{array}{l}\text { Histologic grade } \\
\text { I } \\
\text { II } \\
\text { III }\end{array}$ & $\begin{array}{r}16 \\
13 \\
9\end{array}$ & $\begin{array}{l}1 \\
2 \\
2\end{array}$ & $\begin{array}{r}15 \\
11 \\
7\end{array}$ & 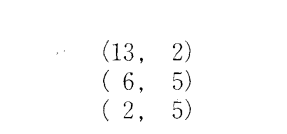 \\
\hline $\begin{array}{l}\text { Outcome } \\
\text { Alive } \\
\text { Dead } \\
\text { Unknown }\end{array}$ & $\begin{array}{r}33 \\
7 \\
1\end{array}$ & $\begin{array}{l}6 \\
0 \\
0\end{array}$ & $\begin{array}{r}27 \\
7 \\
1\end{array}$ & 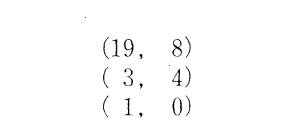 \\
\hline
\end{tabular}

$\star$ Unclassified means tumor with partly serous and partly mucinous carcinoma components.

The analysis using flow cytometry allows the retrospective study of archival material where the clinical outcome is already known. Recently, the extensive application of this high-speed method for analytical cytology has resulted in a large number of data on ploidy disturbances in different types of human carcinomas. DNA ploidy abnormalities were demonstrated in $50 \%$ to $100 \%$ of most human malignant tumors.

There is increasing evidence that in ovarian carcinomas tumor ploidy is of considerable prognostic value with respect to survival.

The aim of the present study was to investigate whether the flow cytometric analysis of DNA ploidy pattern would be a useful adjunct to the histopathological diagnosis of tumors of LMP in the same way as in patients with carcinoma.

\section{MATERIALS AND METHODS}

\section{Patient material}

Paraffin-embedded tumor samples for flow cytometric analysis were obtained from 67 patients with ovarian tumor. In the past 6 years, 16 patients with tumor of LMP were diagnosed and treated in the Jikei University School of Medicine. And initial surgery was carried to 41 patients with primary ovarian epithelial carcinoma in the institution between April 1985 and January 1988. Ten patients with adenoma were selected with random sampling for this study.

The clinicopathologic features of the 41 cases with carcinoma are summarized in Table 1 . The clinical follow-up period was 6 to 39 months. The carcinoma was staged according to the International Federation of Gynecology and Obstetrics system of staging. 
Forty patients with carcinoma were treated with cisplatin combined with adriamycin and cyclophospamide for postoperative chemotherapy according to the protocol of the institution. Only one patient received the combined chemotherapy before surgery.

Histopathologic classification was done according to the World Health Organization histologic typing of ovarian tumors. The carcinomas were graded as being well, moderately, and poorly differentiated on the basis of the proportions of glandular/papillary areas versus solid growing areas. The microscopic evaluation was performed from a slide corresponding to the block used for flow cytometric analysis.

\section{Flow cytometry}

The method used for the prepalation, staining, and analysis of paraffin-embedded tumors for flow cytometry were modified from the procedure developed by Hedley and coworkers. All samples were analysed on an EPICS-V flow cytometer (Kurter Counter Company). $30 \mu \mathrm{m}$ sections were cut using a microtome, and adjacent $3 \mu \mathrm{m}$ section was obtained for hematoxylin and eosin staining to ensure that there was adequate tumor tissue in the block. The sections were placed in $10 \mathrm{~m} l$ glass centrifuge tubes and dewaxed using two changes of xylene, $5 \mathrm{ml}$ for 60 minutes at room temperature, and then rehydrated in a sequence of $5 \mathrm{ml}$ of ethanol/xylene, 100, 96, 70, and $50 \%$ ethanol for 30 minutes each at room temperature. The tissue was then minced and resuspended in $5 \mathrm{ml}$ of $0.25 \%$ trypsin, in citrate buffer (3 $\mathrm{mM}$ trisodiumcitrate, $0.1 \% \mathrm{v} / \mathrm{v}$ Nonidet P $40,1.5 \mathrm{mM}$

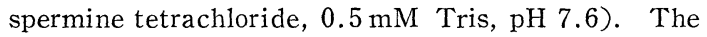
tubes were placed overnight in a waterbath at $37^{\circ} \mathrm{C}$. The suspension was centrifuged and the pellet resuspended in $70 \%$ ethanol. Propidium lodide was used for DNA fluorochromes. Peripheral blood lymphocytes were used as reference diploid cell population.

A single peak with a coefficient of variation (CV) $\leqq 5.5 \%$ were classified as diploid. Mean CV of the diploid DNA peak was $3.7 \%$ (range, $2.8 \% \sim 5.5 \%$ ). The $\mathrm{CV}$ is defined as $\mathrm{CV}=\mathrm{S} / \mathrm{x} \times 100$, where $\mathrm{S}$ is the standerd deviation, and $\mathrm{x}$ the mean of the distribution and is a measure of the peak width; the lower the $\mathrm{CV}$, the greater the resolving power of the tec- hnique. An additional peak was taken to indicate aneuploidy, and the tumor was classified as multiploid when two or more distinct peaks were present. Most of the aneuploid tumors had a peak in the triploidtetraploid range. Tumors with diploid were defined as normal ploidy tumors, and tumors with aneuploid or multiploid were considered as abnormal ploidy tumors. When on this basis, all samples were separated into a normal and abnormal ploidy group.

\section{Statistical method}

Survival was calculated from the start of the treatment and survival time was defined as the period between the initial surgery and death due to ovarian carcinoma. Survival analysis with covariates (Caplan Meiyer method) was done. Statistical significance of survival of survival differences was calculated by a Mantel-Cox test.

\section{RESULT}

Some examples of DNA histograms for paraffinembedded tumors with diploidy, aneuploidy and multiploidy pattern are given in Figure 1 . The majority of patients with carcinoma (83.9\%) ranged between 40 and 60 year-old. Age at diagnosis have no prognostic value for either survival or progression free survival. No attempt was made to correlate age at diagnosis with degree of DNA ploidy pattern in view of the small numbers involved (Table 1).

Among ovarian carcinomas the percentage of cases with abnormal ploidy pattern is six times higher $(85.4 \%)$ than those of the diploid variants (14.6\%) and number of cases with aneuploidy is two times larger (23 cases) than those with multiploidy (12 cases).

Data presented in Table 1 refer to the relationship between DNA ploidy abnormalities and clinical stage or the grade of differentiation of ovarian carcinomas. They show there is no siginificant difference among clinical stages. And no substantial differences in the percentage of cases with ploidy abnormalities were found among the grades, but it is evident that the higher the grade of morphologic pleomorphism, the higher the percentage of cases with multiploidy. 
ADENOMA

Fig. 1 DNA histograms of ovarian tumors Horizontal axis : fluorescence intensity proportional to DNA content; vertical axis : number of cells.

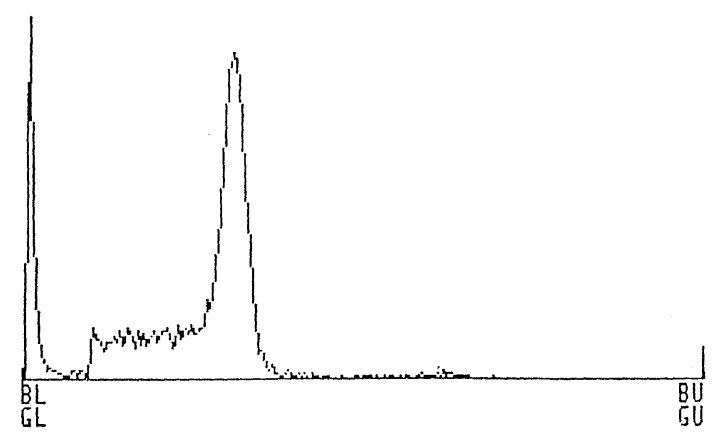

Fig. 1-(1)

\section{SEROUS CYST ADENOCARCINOMA}

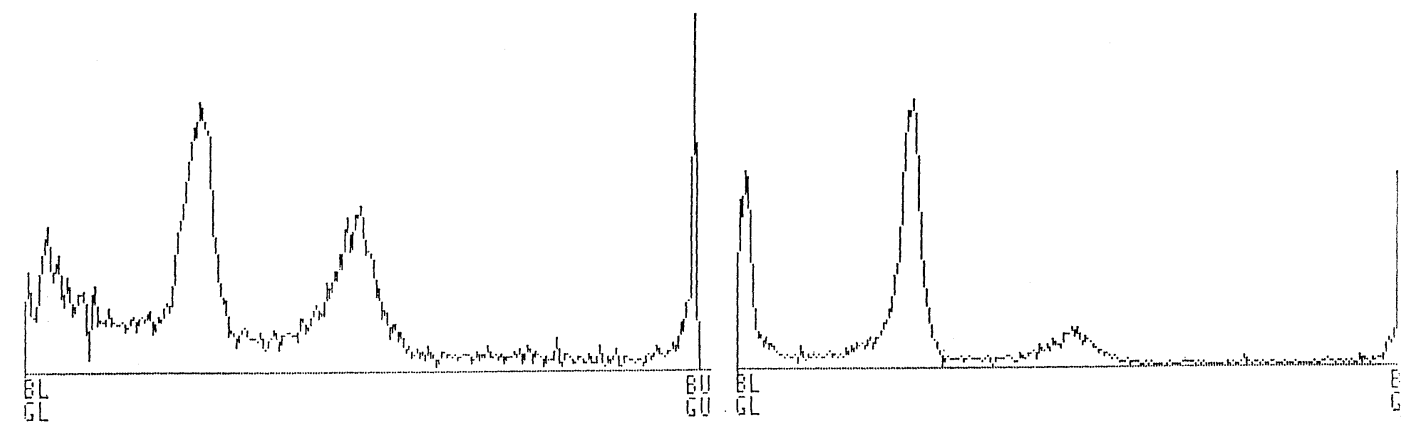

Fig. 1-(2)

MUCINOUS CYST ADENOCARCINOMA

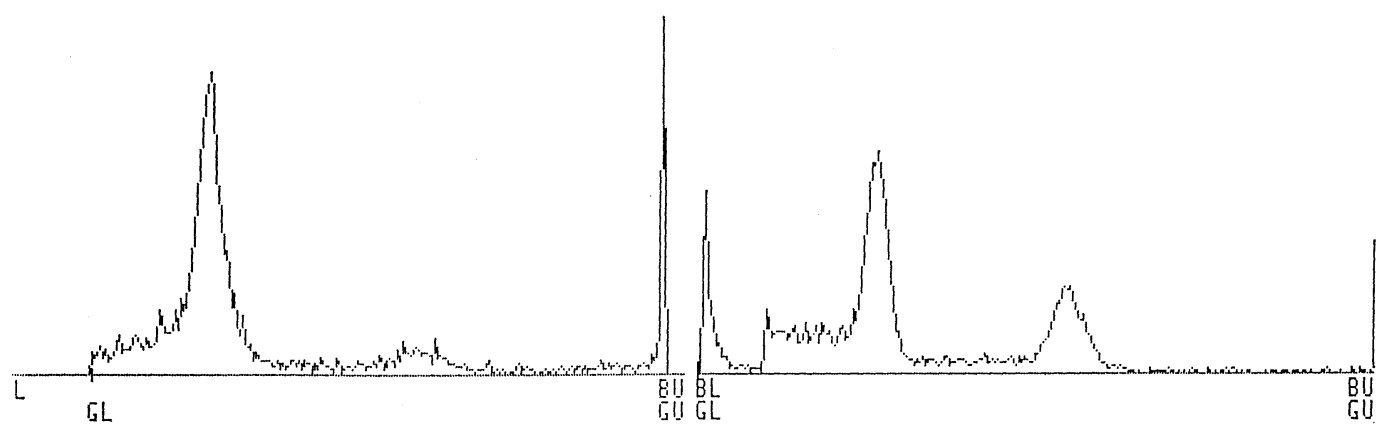

Fig. 1-3

The survival curve for the normal and abnormal ploidy groups according to the Caplan-Meiyer regression model are shown in Figure 2. One case was excluded from the analysis because of inadequate follow-up data. Of the remaining 40 cases with carcinoma, 7 died of the disease, and all of these fatal cases had abnormal ploidy. The follow-up per- iod was too short for tumor ploidy to be found statistically significant effect on survival.

The distribution of ploidy abnormalities in the ovarian tumors containing carcinoma, LMP, and adenoma was presented in Table 2. Of the 16 cases with the tumor of LMP, only one had tumor recurrence during the follow-up period. In this re- 


\section{ENDOMETRIOID CARCINOMA}
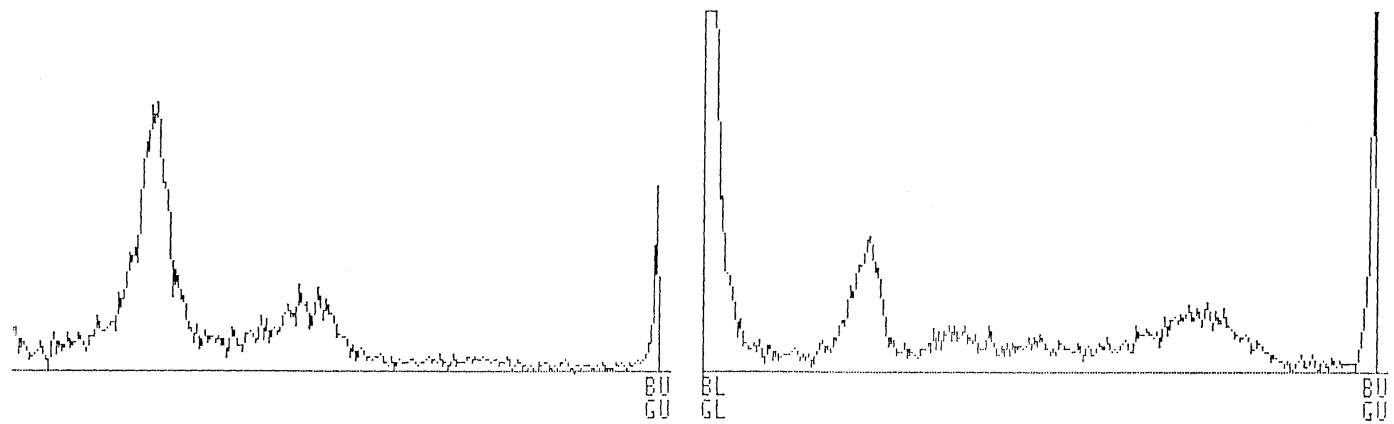

Fig. 1-(4)

UNDIFFERENTIATED ADENOCARCINOMA

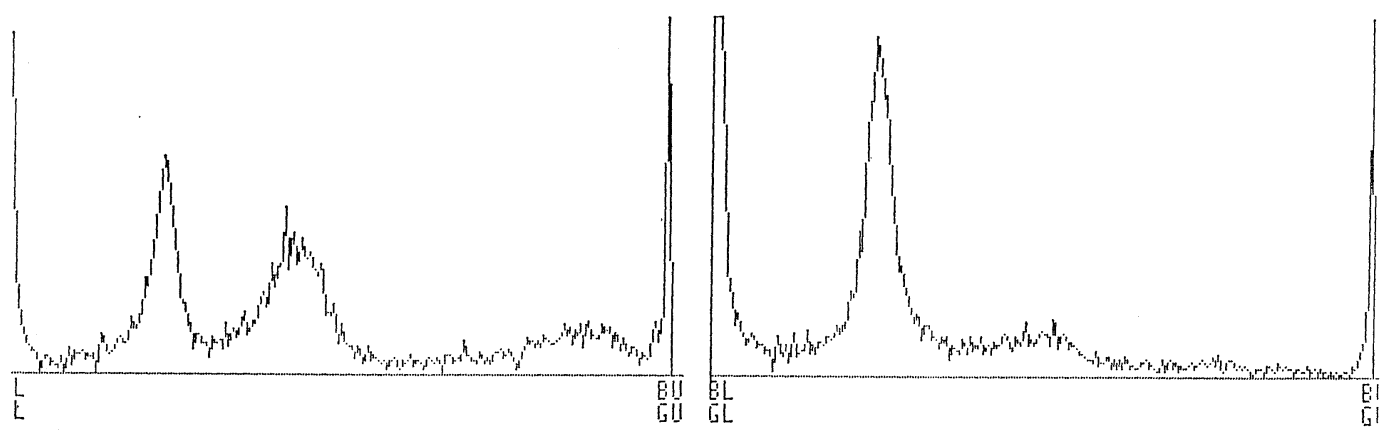

Fig. 1-(5)

MESONEPHROID CARCINOMA

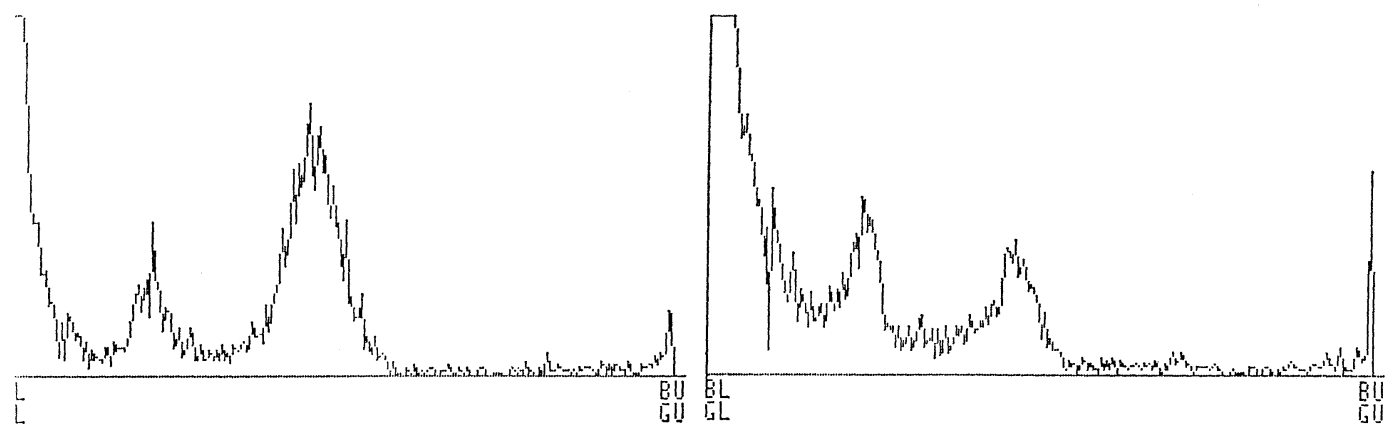

Fig. 1-(6)

currence multiploid was evaluated both in the primary tumor. Of the total 67 analyzed ovarian tumors, 10 had recurrence (including one tumor of LMP) and among them only one had diploidy pattern. This case with diploidy was characterized as mucinous adenocarcinoma, grade 1 and alive without disease.

\section{DISCUSSION}

The classification by the International Federation of Gynecology and Obstetrics is based primarily on the 

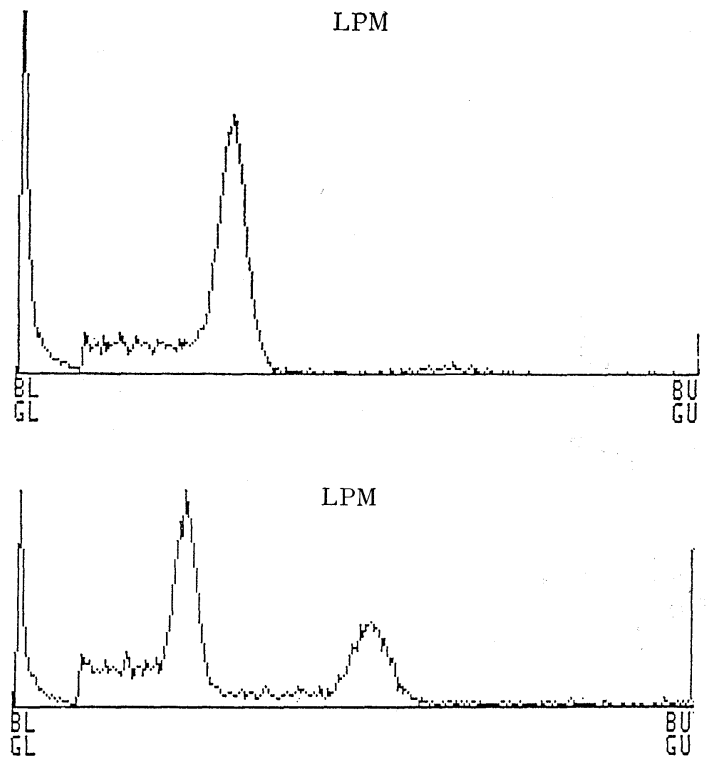

Fig. 1-7)

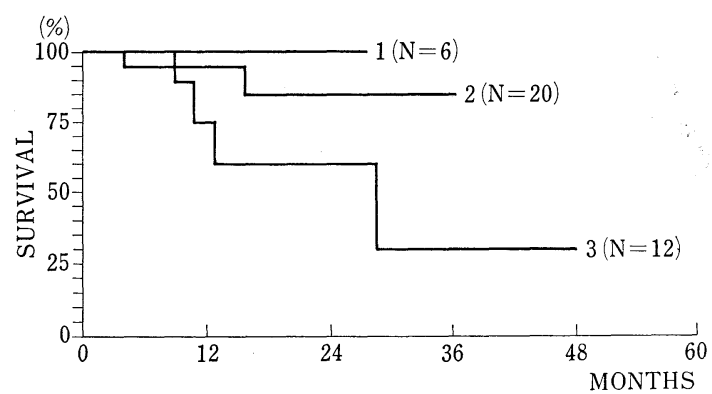

Fig. 2

microscopic characteristics of the tumors. The World Health Organization reports that tumor of LMP can be defined as a tumor that has some, but not all, of the morphologic features of cancer; those present include, in varying combinations, stratification of epithelial cells, apparent detachment of cellular clusters from their sites of origin and mitotic figures and nuclear abnormalities intermediate between those of clearly benign and unquestionably malignant tumors of a similar cell type: on the other hand, obvious invasion of the stroma is lacking. But the estimation of stromal invasion is not always easy.

According to the report by the Ovarian Tumor Registration Committee of Japan Society of Obstetrics and Gynecology, Serous tumor of LMP occured about 10 earlier on average than serous frank malignancy
Table 2 Distribution of histologic evaluation with DNA ploidy

\begin{tabular}{lccc}
\hline & & \multicolumn{2}{c}{ DNA ploidy pattern } \\
\cline { 3 - 4 } & No. & Normal & Abnormal \\
\hline Carcinoma & 41 & 6 & 35 \\
LMP & 16 & 15 & 1 \\
Adenoma & 10 & 10 & 0 \\
\hline
\end{tabular}

and especially more frequently at 29 years of age or under. On the countrary, the difference in average age for the mucinous tumors of LMP and frank malignancy is not more than 3 years. The incidence in each age range has no features like the serous tumor of LMP that distinguish it from serous frank malignancy.

On the other hand, the 5 year survival rate of stage II to IV mucinous tumors of LMP were widely different according to investigators, ranging from 0 to $100 \%$. It is considered that the difference in 5 years survival rate between various investigators was partly due to the small number of the cases. But when this difference of survival rate is taken into consideration as well as the findings that the ageincidence distribution pattern for the mucinous tumor of LMP was similar to that for frank malignancy and different from that for the serous tumor of LMP, there seems to be a problem in diagnosis of the mucinous tumor of LMP itself. It emerges that the mesurement of DNA content is able to be helpful in making the diagnosis of LMP.

Many investigators have suggested that patients with malignant DNA aneuploid ovarian tumors survived significantly shorter than did those with DNA diploid tumors. Our preliminary observations on survival of patients support the results cited above. Thus, seven out of 40 cases with carcinoma died of the disease, and all of these fatal cases had abnormal DNA ploidy pattern. And it was evident that the higher the grade of histologic malignancy, estimated by the criteria of conventional light microscopy, the higher the incidence of cases with multiploidy in this study. But our data could not indicated that significant correlation between the grade and DNA abnormalities in ovarian carcinomas. This divergence from the results by other authers might be 


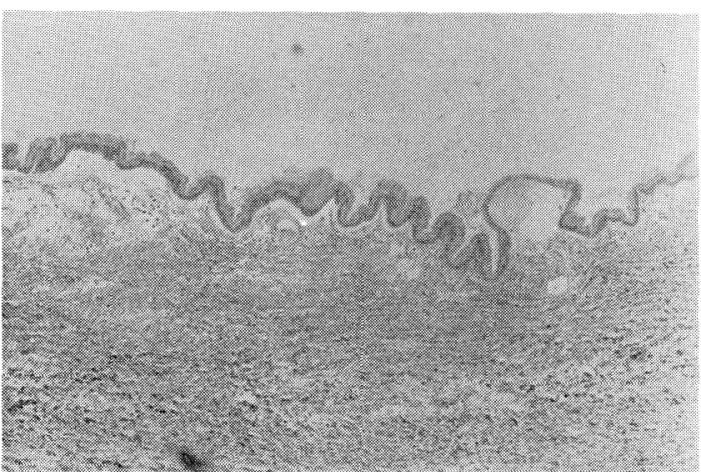

(1)

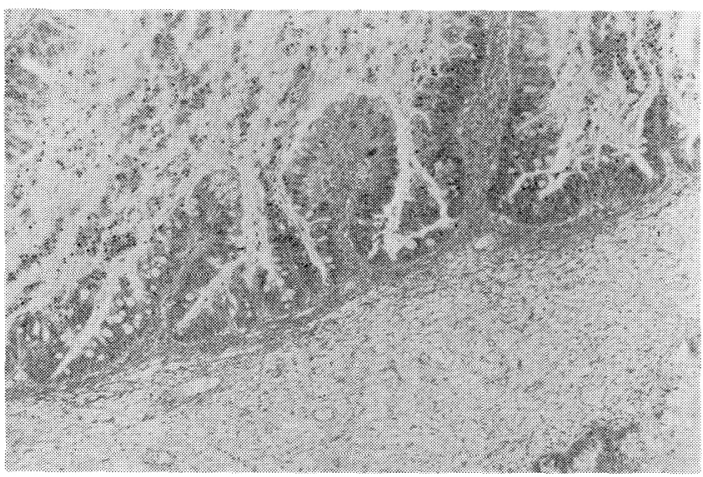

(2)

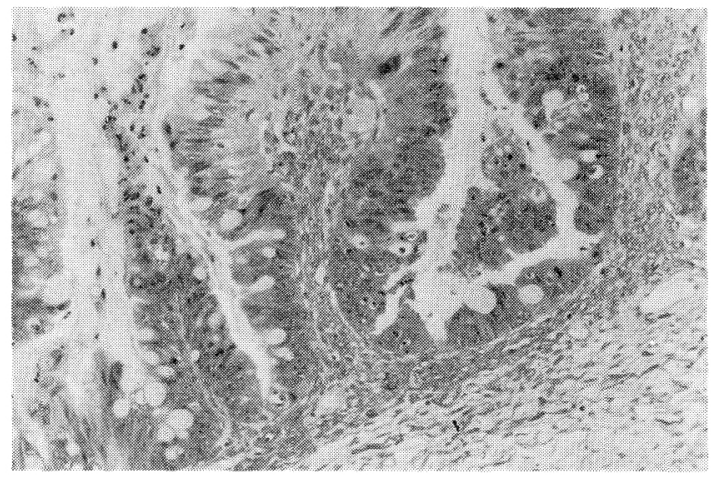

(3)

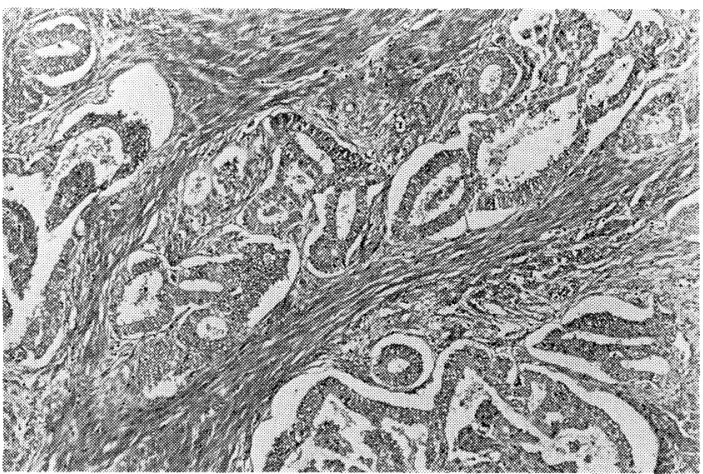

(4)

Fig. 3 HE pictures of a case with tumor of $\operatorname{LMP}(1,2,3)$

This case has an episode of recurrence with cancer (4) 4 years after initial surgery

explained by the small number of carcinomas with normal DNA content.

The reasons of the fundamental biologic differences betwen tumors with normal and abnormal DNA content are unclear. Recently accumulating evidence suggests that DNA aneuploid cell populations have a higher proliferative activity than diploid cells. The bad prognosis of aneuploid tumors might be related both to DNA content abnormalities and to the higher proliferative activity of aneuploid cell lines.

From our data concerning abnormalities of DNA ploidy pattern in ovarian tumors it is evident that benign ovarian tumors are composed of DNA diploid cells. As for the malignant tumors, they can be divided into two groups: those composed of DNA diploid cells only, and those composed of DNA diploid and DNA aneuploid or multiploid cells. In $85.4 \%$ of carcinomas cell population with abnormal DNA content were observed. Only one out of 16 cases with LMP composed of multiploid cells. This case is Stage I a serous papillary cystadenoma of LMP. Salpingo-oophorectomy was done in 1981. Although postoperative chemotherapy was completed, a fistsized tumor was recognized in 1985 and surgical specimens revealed endometrioid papillary adenocarcinoma (Figure 3). This recurrent tumor composed of multiploid cells similer to initial tumor of LMP. This case suggests the importance of a careful follow-up such patients with LMP composed of abnormal ploidy cells. In this study 7 died of the disease, and all of these fatal cases had abnormal DNA ploidy pattern. It is possible that a tumor of LMP with abnormal ploidy pattern may have a very different natural history than those with normal ploid, but further follow-up is required to establish this. 


\section{要 約}

卵巣腫瘍 67 症例の DNA ploidy patternを,そのパラフィン包 埋切片からフローサイトメトリーを使用して分析した. 卵巣腫瘍 の内訳恃, 腺腫 10 例, 癌腫 41 例, 低悪性度群 16 例であった. フローサイトメトリーによる DNA 分析用の染色は, propidium iodide を用いた. 腺腫 10 例はすべて, diploidy pattern であっ たのに対して, 癌腫では, その $85.4 \%$ が aneuploidy もしくは multiploidy pattern を呈していた. 一方, 低悪性度群では, 16 例中 15 例は腺腫と同様に diploidy pattern であった. しかし， 低悪性度群で multiploidy pattern を呈した症例が 1 例存在し, その症例は, 初回治療の 4 年後に再発をきたし, その再発腫瘍の 病理所見は, 癌腫であった.このことから, DNA ploidy pattern の分析は, 卵巣腫瘍低悪性度群に対する従来の病理組織学的診断 の一助となりうる可能性が示唆されるが, 臨床応用するために は, 今後の検討が必要である.

\section{REFERRENCES}

1) Aure, JC., Hoeg, K., Kolstad, P. : Clinical and histologic studies of ovarian carcinoma: Long-term followup of 990 cases, Obstet. Gynecol., $37: 1 \sim 9,1971$.

2) Barlogie, B., Rober, MN., Schumann, J. : Flow cytometry in clinical cancer research, Cancer Res., $43:$ 3982 3997, 1983.

3) Bostwick, DG., Tazelaar, HD., Ballon, SC., et al. : Ovarian epithelial tumors of borderline malignancy; a clinical and pathologic study of 109 cases, Cancer, $58: 2052 \sim 2065,1986$.

4) Christov, K., Vassilev: Flow cytometry analysis of DNA and cell Proliferation in ovarian tumors, Cancer, $60: 121 \sim 125,1987$.

5) Creasman, WT., Park, R., Norris, H., et al. : Stage I borderline ovarian tumors, Obstet. Gynecol., $59: 93 \sim$ 96, 1982.

6) England, MJ., Sonnendecker, EWW., Margolius, KA. : Epithelial ovarian tumours of low malignant potential, S. Afr. Med. J., $70: 543 \sim 548,1986$.

7) Erhardt, K., Auer, G., Björkholm, E., et al. : Prognostic significance of nuclear DNA content in serous ovarian tumors, Cancer Res., 44 : 2198 2202, 1984.

8) Feichter, GE., Kühn, W., Czernobilsky, B., et al. : DNA flow cytometry of ovarian tumors with correlation to histopathology, Inter. J. Gynecol. Pathol., 4 : $336 \sim 345,1985$.
9) Frankfurt, OS., Slocum, HK., Rustum, JM.:Flow cytometric analysis od DNA aneuploidy in primary and metastatic human solid tumors, Cytometry, $5: 71 \sim 80,1984$.

10) Friedlander, ML., Taylor, IW., Russel, P., et al. : Ploidy as a prognostic factor in ovarian cancer., International J. Gyne. Pathol., 2 : 55 63, 1983.

11) Friedländer, ML., Hedley, DW., Taylor, IW., et al. : Influence of cellular DNA content on survival in advanced ovarian cancer, Cancer Res., $44: 397 \sim 400$, 1984.

12) Hedley, DW., Friedlander, ML., Taylor, IW., et al. : Method for analysis of cellular DNA content of Paraffin-embedded pathological material using flow cytometry, J. Histochem. Cytochem., $31: 1333 \sim 1335$, 1983.

13) Kallioniemi, OP., Punnonen, R., Matila, J., et al. : Prognostic significance of DNA index, multiploidy, and S-phase fraction in ovarian cancer, Cancer, 61 : 334 339, 1988.

14) Kliman, L., Rome, RM., Fortune, DW.: Low malignant potential tumors of the ovary: A study of 76 Cases, Obstet. Gynecol., $68: 338 \sim 344,1986$.

15) Laerum, OD., Farsund, T. : Clinical application of flow cytometry: a review, Cytometry, $2: 1 \sim 13,1981$.

16) Lovett, E. III., Schnitzer, B., Keren, DF., et al. : Application of flow cytometry to diagnostic pathology, Lab. Invest., $50: 115 \sim 140,1984$.

17) Nation, JG., Krepart, GV.: Ovarian carcinoma of low malignant potential: Staging and treatment, Am. J. Obstet. Gynecol., $154:$ 290 293, 1986.

18) Nikrui, N.: Survey of clinical behavior of patients with borderline epithelial tumors of the ovary, Gynecol. Oncol., $12: 107 \sim 119,1981$.

19) Rodenburg, CJ., Cornelisse, CJ., Heintz, PAM., et al. : Tumor ploidy as a major prognostic factor in advanced ovarian cancer, Cancer, $59: 317 \sim 323,1987$.

20) Scully, RE.: Ovarian tumors: A review, Am. J. Pathol., $87: 686 \sim 720,1977$.

21) Tasker, M., Langley, FA.: The outlook for women with borderline epithelial tumours of the ovary, Br. J. Obstet. Gynecol., $92: 969 \sim 973,1985$.

22) Volm, M., Brüggemann, A., Günther, M. : Prognostic relevance of ploidy, proliferation and re sistence-predictive tests in ovarian carcinoma' Cancer Res., 45 ; $5180 \sim 5185^{`} 1985$. 